\title{
Enhancing e-commerce by website quality
}

\author{
Renata Bilkova \\ Department of System Engineering and Informatics \\ University of Pardubice \\ Pardubice, Czech Republic \\ renata.bilkova@upce.cz
}

\author{
Hana Kopackova \\ Department of System Engineering and Informatics \\ University of Pardubice \\ Pardubice, Czech Republic \\ hana.kopackova@upce.cz
}

\begin{abstract}
Competition among e-commerce sites challenges their providers to look for new ways of customer attraction. Website quality can be included among the fundamental tools (along with the information and service quality) to attract and retain customers. In this article is described experiment covering establishment of e-shop as the competitor to producer website. New e-shop has defined terms, services are assured by producer therefore the only way how to compete is through website quality. During the reporting period producer applied discount actions, which allow us to determine the influence of the price and non-price competition.
\end{abstract}

Keywords-E-commerce; website quality; non-price competition; SEO optimization.

\section{INTRODUCTION}

The growth of electronic retail is impressing as evidenced by $18,2 \%$ grew to an estimated 200,52 billion Euros in 2011 according to Centre for Retail Research [1]. In the Czech Republic, can be seen parallel trend in e-commerce growth, as the Internet retailing in goods amounted to 43 billion CZK in 2012 [2] and it ranked the Czech Republic to the top in Europe.

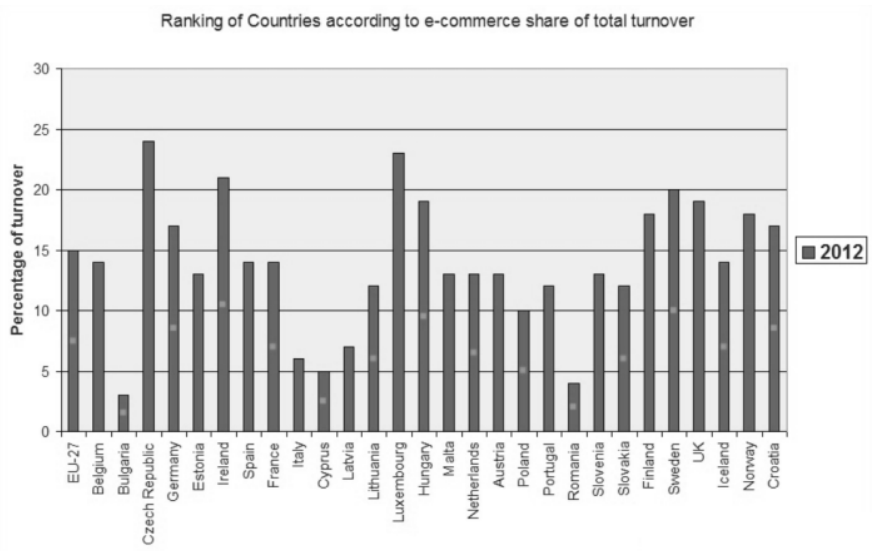

Fig. 1. Turnover from e-commerce in 2012: source [3]

Fig. 1 shows that e-commerce in the Czech Republic is on the high level in comparison with other countries. Competition among electronic retailers on the Czech market is very strong, which forces companies constantly look for new ways to attract customers. Any e-commerce website on this market is just one of hundreds of thousands lost in a sea of online stores demanding an attention.
Popularity of electronic shopping is given by many factors; first of all it is the lower price that enables consumers to save money in the electronic stores. Equally important factor is increased online choice that leads to much vice decisions in order to choose right goods. European study of e-commerce [4] found that saving of money is prevalent reason followed by saving time, easier comparison of price and enhanced availability (24/7). Other benefits of using e-commerce for companies, consumers and society are explained in [5].

Each company selling online (but even offline) tries to find more about its customers in order to sell more goods and make bigger profits. As in offline retail (brick-and-mortar stores) it is very complicated to obtain information about number of visitors, time spent in store, where these customers come from and so on, it is quite easy to get them in online retail. Such numbers and statistics can be obtained through web analytic tools and used for the adjustment of marketing strategies in order to convert potential customers to real ones and retain them. Web analytic tools can be also used by web site designers, to enhance web accessibility and usability.

Using of web analytics for studying non-price competition in e-commerce environment is topic of this article. Focus of the study is primarily given to the question if it is possible to build new e-shop that will be competitive (through web analytic tools) against producer e-shop having the same goods and same prices.

\section{PROBLEM FORMULATION}

Importance of online sales increased highly during last 10 years. Growths that can be seen in Fig. 2 represent tripling in last decade.

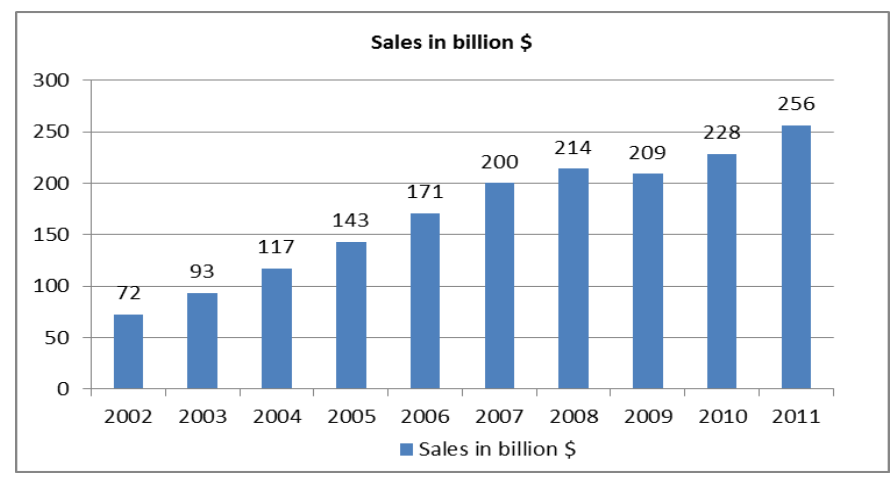

Fig. 2. E-commerce growth in 2002-2011: source [5] 
Wide spread of online shopping has stimulated extensive research aimed at attracting and retaining consumers from two points of view; technological and consumer oriented view. Web designers perceive commercial success of e-shop as a matter of purely technical features such as user interface features, Web site content and design, and system usability. Whereas marketers study factors influencing willingness to buy online and reasons for selection of particular shop from the behavioural point of view. For example online consumer behaviour has been examined according to perceptions of risks and benefits toward online shopping [6],[7][8],[9],[10], [11]. Teo and Liu [12] found that the positive relationships exist between consumer trust and their attitude toward a vendor and between consumers' attitude and their willingness to buy from it. The above two views do not contradict but rather complement each other. In our study we concern mostly on the technological view of the problem.

Consumers use different research strategies when preparing to purchase a product. The consumer survey [4] shows which steps respondents took first, second and third, when researching their most recent online purchase costing more than 30 Euro. The various steps which respondents could choose included common online strategies such as using search engines, visiting retailer websites, or visiting price comparison websites, as well as common offline strategies such as visiting shops, viewing reports and advertisements in media, or discussing with friends or colleagues. When the three steps were combined, the most popular strategies for EU online shoppers researching a purchase were all online strategies: visiting seller websites (31\%), using a general search engine such as Google, Bing or Yahoo (30\%), using a price comparison website $(27 \%)$ and also popular was reading customer reviews online $(26 \%)$.

According to SeeWhy Research [13] more than half of the traffic arriving to e-shop websites coming under e-mail suggestion $(57 \%)$. Direct traffic contributes $18 \%$, search engines $10 \%$, SEM and link building which contains also price comparison website $9 \%$.

The consumer survey [4]; in the Czech Republic, almost $92 \%$ of all customers uses the price comparison websites, which is the most of all EU countries.

The main reason, why sellers use services of these servers is that the typical visitor comes to the price comparison website with the intention to find and buy particular product. Commodity search through this channel brings to the e-shop a lot more targeted traffic in comparison with other sources of traffic (full text search engines, catalogs ...) and reach several times larger conversion ratios.

Consumer decision is driven not only by price comparison websites but also by comparison with offline stores.

European study of e-commerce [4] identified two way exchange of information before the purchase. "Online shoppers use offline methods to research products, such as going to shops, or reviewing mail order catalogues. Conversely, online sources, such as sellers' or manufacturers' websites, online review or price comparison websites are used by consumers who make offline purchases."
From this study raised obvious fact that virtual companies are in more difficult situation than companies using internet as an additional channel for enhancing their sales. These offlineonline companies can benefit from interconnection of electronic and real world (people know the brand from brickand-mortar stores).

As Internet shopping gradually move from a novelty to a routine way of shopping, the quality of e-commerce sites will play an important role in differentiating sites. High quality sites are able to attract more browsers and shoppers than competing low quality sites. Yoo and Donthu in [14] described calculation of quality indicators. They can be divided into two categories; vendor-related factors and quality related factors. Vendorrelated factor covers competitive pricing, clarity of ordering, the name value of site owner, uniqueness, product quality assurance. Quality factors were: ease of use, design, processing speed, and security.

Different view on the quality brings for example Collier and Bienstock [15]. They proposed conceptual model that expects consumers to form quality evaluations based on the interactive process that takes place online (process), the outcome of how the product or service is delivered (outcome), and the manner in which service failures (if they occur) are handled (recovery).

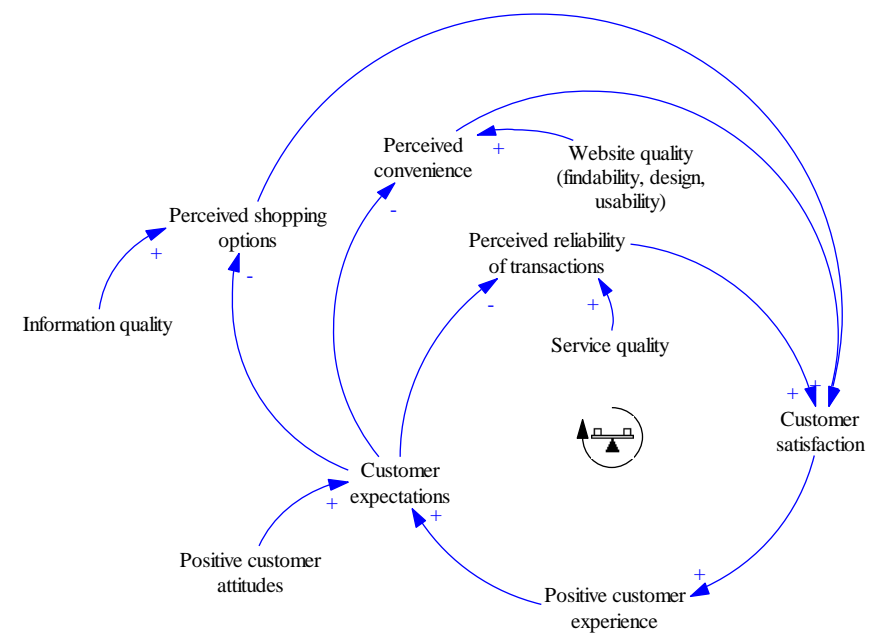

Fig. 3. Causal loop diagram displaying building blocks of customer satisfaction

In our research we want to show that quality of e-commerce site can have great impact on consumer satisfaction that forces intention to buy goods. Fig. 3 shows position of website quality in our concept. This graphical representation demonstrates influence of customer satisfaction and personal attitudes on expectations of customers. Simultaneously, we can see that high expectation with inadequate quality (information, website, service) can bring reduction in customer satisfaction. The main problem is that the reduction in only one aspect of quality can reduce customer satisfaction. Websites those are not able to fulfil customer expectations and follow contemporary trends in 
order to meet customer expectations are going to have problems.

\section{METHODOLOGY OF RESEARCH}

The main problem of quality evaluation is high dimensionality. Many studies tried to overcome this problem, using analytical and statistical methods. In our study we decided to use different approach. We prepared the experiment; in which new e-commerce site was built to prove that pure website quality can bring purchases while other factors are obeyed. Website quality is here defined as composed of three features:

- findability (the ability of users to find an appropriate Web site),

- usability (the ease of use and learnability),

- user-friendly design.

Our experiment is based on comparison of two websites, first website operated by producer, with producer name in URL, having also offline sales channels. On the other side we put new e-commerce site operated by creator of the site, having the same prices and terms and conditions, with expedition of goods done by producer. The only way how this site can compete is quality of e-shop based on findability, usability and design.

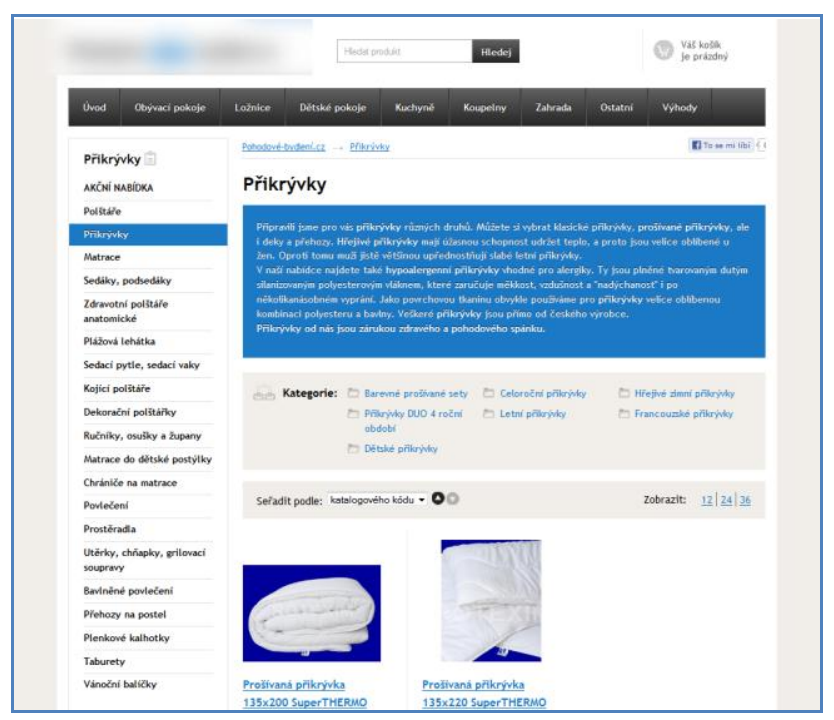

Fig. 4. New e-shop website

Comparing the possibilities of both sites suggests that the producer site can highly benefit from promotion in offline channels. While the new site, must rely on the Internet sources for promotion and need to convince customers that it is worth to use this e-shop.

As the primary source of potential customers we selected database of actual customers of the company that created the eshop. These customers obtained e-mail newsletter with the information about new e-shop.

In parallel with the creation of the newsletter, some products have been added to price comparison webs.
Regarding [16] and [17], the most frequently used price comparison websites in the the Czech Republic are Zbožícz (55\%), operated by the SEZNAM.cz and Heureka.cz (41\%). Other competitors have only 1-2\% share. Thus the new ecommerce site created export feeds into these two strongest players in the marketplace.

Efforts to increase sales in the next period focused on creation of the most successful SEO optimization strategy of website. For both e-shops have been chosen search optimization targeted on Seznam.cz mainly for two reasons. First of all it is the most popular search engine in the Czech Republic [18]. Second reason was given by creators of new eshop; Seznam.cz is the most common source of traffic for this segment of market.

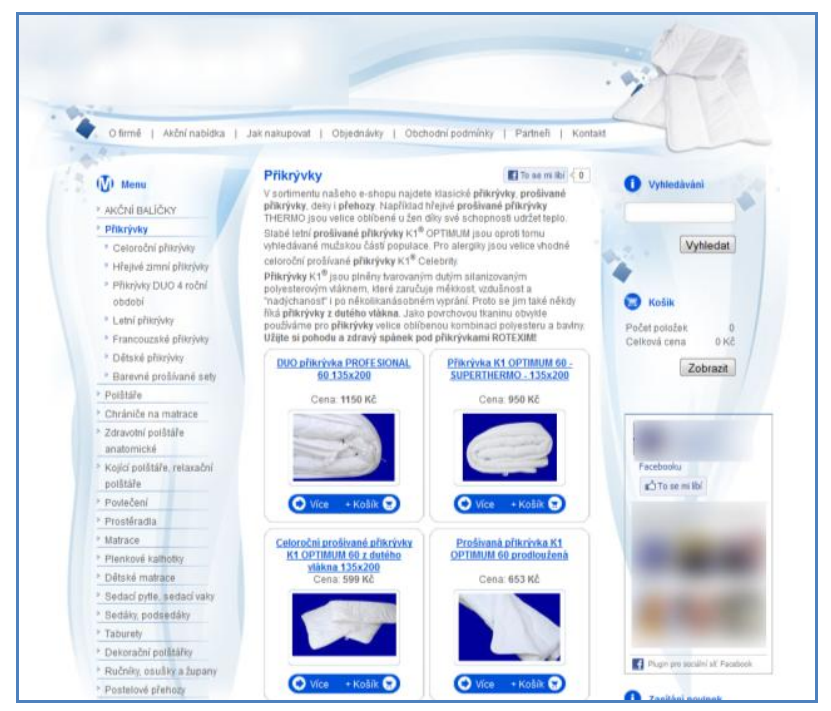

Fig. 5. Producer website

It was clear that in the first months, efficiency of SEO (search engine optimization) would be minimal - the position in the search engine is highly influenced with the history of the site that is minimal. This problem is matter of time so in the future it will disappear.

SEO optimization can be focused on general phrases like (house, pillow) or on long tail phrases like (modern wooden house, pillow 50x70). Focus on highly competitive general phrases is time consuming and financially demanding. Targeting optimization on general phrases also means high competition among other e-shops and omitting of other variants of queries meaning the same product.

Studies [19] tell that users enter rather specific questions, covering general phrases, if they look for particular goods. Those, who entered the general question are just beginning the search for their question and will continue to specify it. In contrast, customers who go to the web with intention to buy are using specific search phrases. This is the targeted group for eshops. The aim of the e-shop is to get customer as close as it is possible to that they're looking for without the need for tracing and the need to browse other sites that customers do not care that much, because here increase the risk of losing customer. The use of longer phrases that are more specific and use 
different keyword variations (long tail phrases) brings higher search efficiency [20].

While the producer e-shop is optimized for general, highly competitive phrases, the aim of new e-shop is optimization on such long tail phrases that customers like to look for and also provide the greatest degree of conversion.

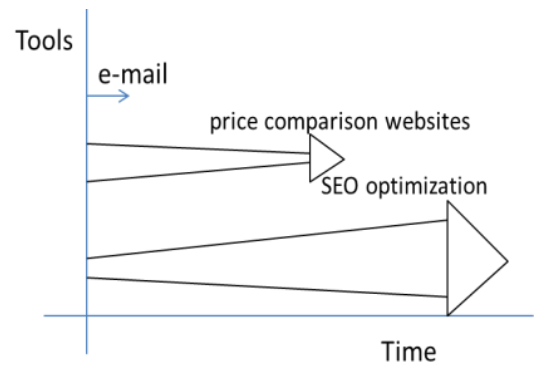

Fig. 6. Intensity of usage of particular tools to increase findability

Three different tools influence the findability of website. Each is used with specific intensity and duration. E-mail newsletter was used only once at the beginning of the project. Price comparison websites are useful but expensive tool that is why the intensity of use is declining. Only carefully selected items are now being there. SEO optimization is the main tool driving attention of consumers in our concept. With the buildup of history in search engines we can rely more on this tool.

Findability represents basic feature of quality in our concept, nevertheless graphic design and good usability of eshop are no less important. Under its form customer evaluates the expected quality of goods and services. Good usability can mean the difference between one site's success and the downfall of another. Usability is especially important in the case of e-commerce websites. While most usability principles of regular websites still apply for e-commerce sites as well, the different specific pages such as shopping carts, shipping methods, shipping and billing addresses, order reviews, payment options, etc. all add another layer of complexity to creating usable online shops. Usability is a prerequisite for an online store to achieve its full potential. For our e-commerce site we used best practices explained in [21],[22],[23], especially clarity, easy orientation and simple pages of purchase.

TABLE I. MEASURES USED FOR COMPARISON OF WEBSITES

\begin{tabular}{|l|l|}
\hline \multicolumn{1}{|c|}{ Measure } & \multicolumn{1}{c|}{ Calculation } \\
\hline Attraction measure & number of visitors per period of time \\
\hline Conversion rate & $\begin{array}{l}\text { ratio of customers who really bought } \\
\text { to all visitors }\end{array}$ \\
\hline Sales & $\begin{array}{l}\text { amount of money obtained in time } \\
\text { period }\end{array}$ \\
\hline Sales per visit & $\begin{array}{l}\text { amount of money obtained in time } \\
\text { period relative to one visit }\end{array}$ \\
\hline Findability measure & $\begin{array}{l}\text { ratio of visitors coming from search } \\
\text { engines to other visitors }\end{array}$ \\
\hline Design and usability measure & conversion rate of returning visitors \\
\hline Customer satisfaction & evaluation of customers \\
\hline
\end{tabular}

Experimental setting needed precise definition of measurable outcomes in order to compare efficiency of both sites. All measures are introduced in Table I and further explained in following text.

Attraction measure is the fundamental measure. E-shop with low attraction measure has inadequate number of visits so it cannot generate high profits. Nevertheless the reverse is not true. People coming just to look increase the traffic but not the profit. High attraction measure is thus a necessary, but not sufficient.

Conversion rate takes into consideration that only some part of traffic is done by visitors willing to buy. This measure shows what portion of visitors spent some money at the e-shop but it does not measure how much.

Sales mean the amount of money obtained in time period. This measure is not specific to electronic commerce on the contrary it is the first measure that interest every businessman.

Sales per visit is the measure that transfer conversion rate to money. This measure is important when thinking about costs of traffic. High traffic costs with low sales per visitor can bring the company into the red despite the popularity of website.

Findability measure is important in this case because of limited possibilities to compete with producer website. New eshop is fully dependent on online channels for promotion. Therefore if we want to minimize promotion costs, search engines are the best way how to attract visitors. Values of this measure should be increasing.

Design and usability measure is defined as conversion rate of returning visitors. People coming to buy again at the same eshop are obviously satisfied. Given that all parameters apart from website quality are the same, it has to be because of the design and usability. Findability that is also part of defined quality does not play a role in this case.

Customer satisfaction is very special measure. Customers are asked to fill a questionnaire and define how satisfied with the trade are they. This measure is supposed to be objective but it can be sometimes tricky. Generally, customers that are satisfied are not really willing to fill this questionnaire because they do not feel any problem and take it as time-consuming.

Results of all described measures in past periods are given in result chapter. Since the experiment is not over yet described results may vary in future reporting periods.

\section{RESULTS}

Experimental e-shop has been launched in December 2011, which is ideal season because of increased sales of all goods.

At the first month, e-shop had already 1608 visits, which is compared to e-shop manufacturer (6190 visits) considerably less, but it was the beginning of the operation and e-shop did not have a built up reputation. Visitors came mostly from comparison websites or directly due to e-mail newsletter. Initial results of this experiment were published in [24]. Now, after 18 months of operation, traffic of new e-shop has tripled, while the manufacturer e-shop declines, number of visitors decreased to half its initial data. See in fig. 7. 


\section{Number of visits}

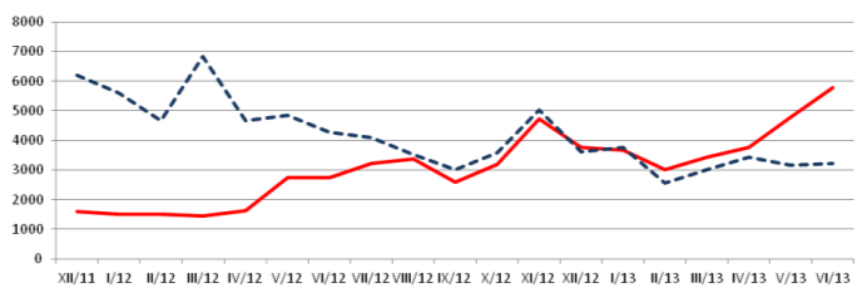

- Newe-shop -----Producer e-shop

Fig. 7. Number of visits at compared e-shops

Attracting shoppers to come into e-shop is one side of the coin but electronic retailers need to sell therefore they have to monitor also other key performance measures. Among the main measures it is conversion rate. Conversion rate is calculated as the rate of number of visits with realised purchase to all visits expressed in percents. The importance of conversion rate is evidenced by survey conducted in 2004, where $81 \%$ of sites were measuring their conversion rates. Forty five percent of those surveyed reported an overall 1 to 4 percent conversion rate [25]. According to Moe and Fader [26] over $70 \%$ of online retailers experienced less than $2 \%$ overall purchase conversion rate. According to another study, the strongest websites have conversion rates of $12 \%$ and the poorest ones have $0,4 \%$ while the average is $2,5 \%$ [27].

In 2011, Forrester Research report [13] puts the typical ecommerce conversion rate at between $2 \%$ and $3 \%$, but says that nearly two-thirds of respondents reported higher rates for the past 12 months.

Average conversion rate for new e-shop in our experiment is $1,87 \%$ in comparison with producer e-shop having $2,90 \%$. In terms of new e-shop progress, we can see that this rate fluctuated initially, but from April 2012 is slowly increasing and now is at $2,05 \%$. Producers conversion rate oscillate mostly between 2 and $3 \%$. Significant increases of conversion ratio are visible during the promotional campaign on the discount portal in March, September and December. Fig. 8 depict conversion ratio for both e-commerce sites.

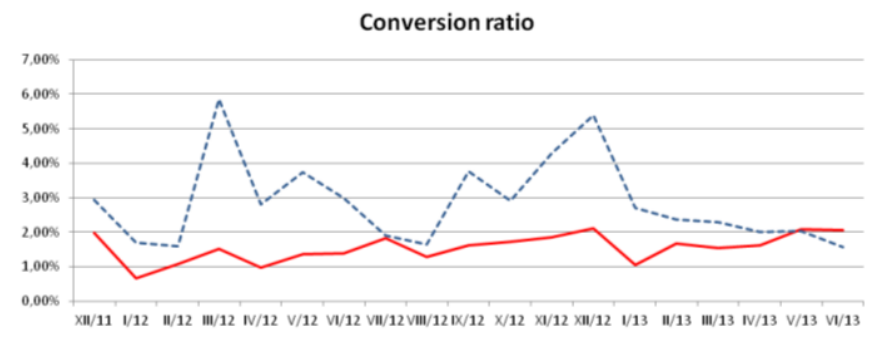

$$
\text { - Newe-shop ------ Producer e-shop }
$$

Fig. 8. Conversion ratio at compared e-shops

From these data it is apparent that at the producer e-shop comes higher percentage of people with intention to buy. It is in contrast with intentions of new site visitors at the beginning. First visitors were mostly curious and came just to look. However, the growing trend of this indicator suggests that the site become known after some time so more people came to buy now.
The present findings are confirmed by changes in sales (expressed in money) that are now twice as high as was in December 2011. For manufacturer we have seen the reverse trend with reduction of sales by about a quarter. At the beginning, manufacturers' e-shop produced more than three times higher sales, while in last month is sales ratio reversed and now the new e-shop volume of sales is more than double to the manufacturers' e-shop, see Fig. 9.

Unfortunately producer disagreed with release of actual sales data that is why we can show only the proportion.

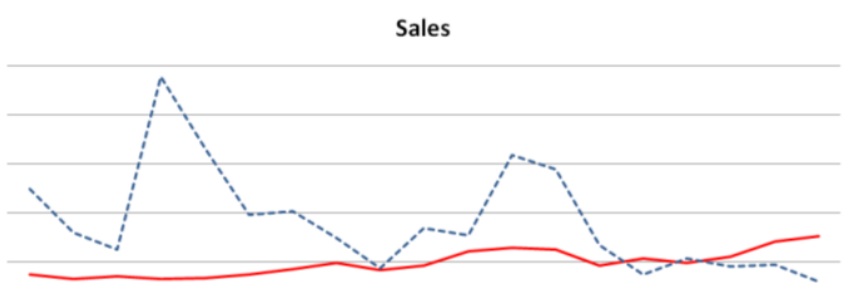

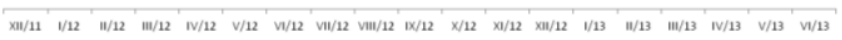

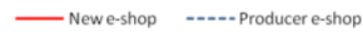

Fig. 9. Sales at compared e-shops

Sales per visit show conversion ratio expressed in money. Reason for the introduction of this indicator is not only to be compared with the cost of traffic, but also we are able to identify influence of promotion actions on discount portals. Comparing Fig. 9 and Fig. 10 we can see that sales per visit sustained quite high in April due to application of discount vouchers one month later. Purchases on the voucher were higher than common purchase on this site.

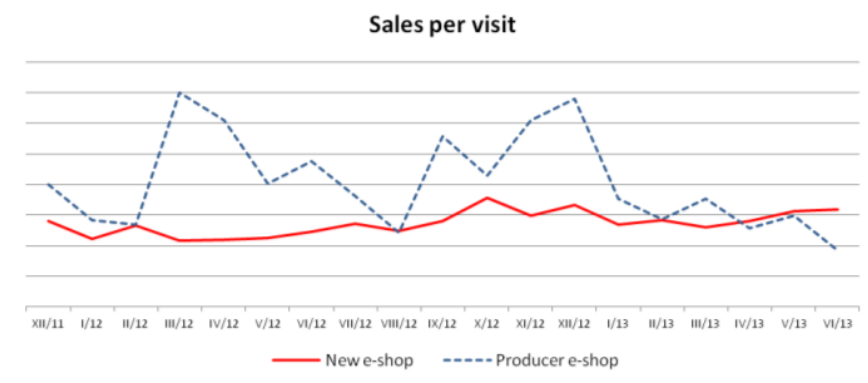

Fig. 10. Sales per visit at compared e-shops

Since 2010, discount portals ranked among a whole new way of online shopping. Behind the emergence of these portals is the idea of collective buying, meaning that a group of users purchase one type of product or service and pay in advance. This form of purchases in the Czech Republic is among the very popular and discount portals have become a really profitable business plan for many people. According to a local survey [28] focused on shopping at discount portals, 49 percent of the adult Czech population used offers of discount sites for shopping.

In the first months of its existence, new e-shop had to acquire their customers without extensive advertising campaign. If we look at the composition of shoppers at the new e-commerce site in the first months of operation of business, the buyers come mainly from price comparison websites. This 
confirms the theory that customers coming from price comparison websites are willing to buy even in a brand new eshop.

Although the absolute number of shoppers coming from price comparison websites remains roughly at the same level, their proportion progressively decreases as increases findability through search engines in accordance with growing percentage of customers coming from this source. See Fig. 11.

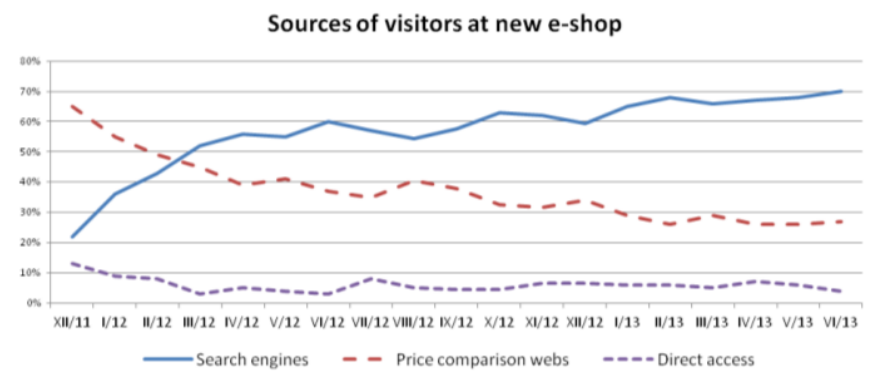

Fig. 11. Rate of visitors coming from different sources

New site have to rely on the Internet sources for promotion therefore the SEO optimization is necessary tool attraction enhancement. Efficiency of SEO (search engine optimization) in the first month was low. Over time, however findability increased to the current $58 \%$ of the traffic, which reached producer level. The difference between traffic sources in new e-shop during the first and the last month of the monitoring period is shown in fig. 12 .

Traffic sources at producer e-commerce site during reporting period did not change significantly. Findability by search engines is at the same level as for the new e-shop at the end of the reporting period. Producer e-shop earn some extra traffic through PPC advertising during the first months of our monitoring and three advertising campaigns for discount portals in March, September and December.
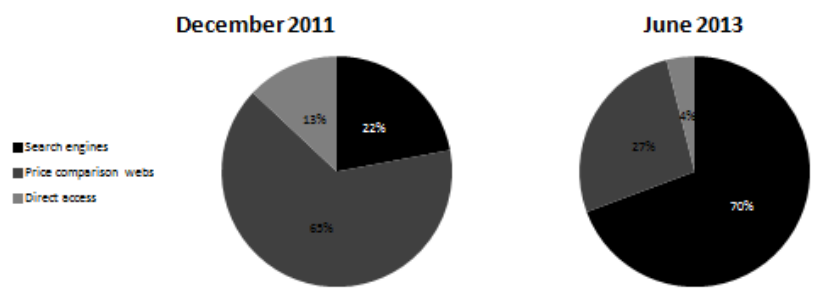

Fig. 12. Comparison of new e-shop traffic sources

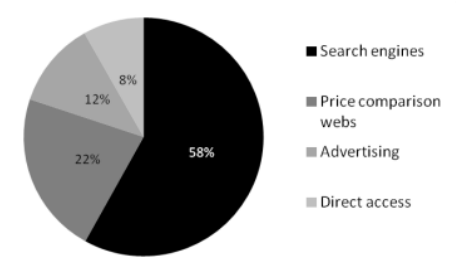

Fig. 13. Producer e-shop traffic sources

Another observed attribute of new e-shop shows how the design and usability of website can influence sales. Measuring of the feature is based on the conversion rate of returning visitors. The basis for the selection of this criterion is the fact that returning user is apparently satisfied with this store. And because all other criteria than the quality of the e-shop was excluded in the measurement, it is obvious that this is because of usability and design of e-shop. Present returning visitor conversion rate for new e-shop is $4,25 \%$ (new visitors only $1,56 \%)$.

Fig. 14 display that values of this parameter approach to the same value nevertheless promotion actions on discount portals are so strong that makes also returning visitors buy additional goods.

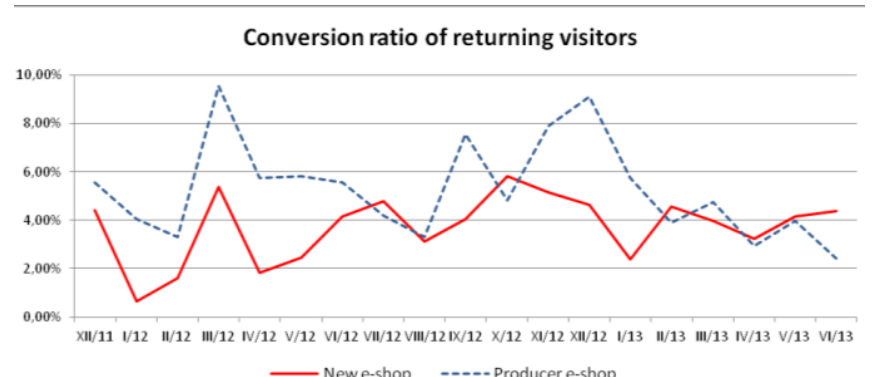

Fig. 14. Conversion ratio of returning visitors

How to find an objective customer evaluation of ecommerce sites? On the Internet there are lots of services attempting to evaluate e-shops. However, the business should be evaluated mostly by customers of these stores. Unfortunately the evaluation is open, so business owners can evaluate themselves (of course, positive), or vice versa competition (obviously negative). This makes such an assessment unusable for decision-making in which shop to buy.

\begin{tabular}{|c|c|c|}
\hline Celková spokojenost & $\begin{array}{l}\text { Dodaci lhúta } \\
\text { Přehlednost obchodu } \\
\text { Kvalita komunikace } \\
\text { Kvalita dopravy }\end{array}$ & 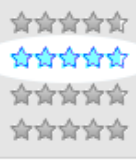 \\
\hline Celková spokojenost & $\begin{array}{l}\text { Dodaci lhúta } \\
\text { Přehlednost obchodu } \\
\text { Kvalita komunikace } \\
\text { Kvalita dopravy }\end{array}$ & 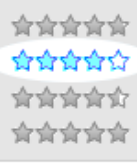 \\
\hline
\end{tabular}

Fig. 15. Customer satisfaction by Heureka.cz

The second reason why such an evaluation is not applicable, is the fact that customers that bought with no problem are satisfied, therefore they have little reason to look for a similar evaluation services. Here we can find mostly people who were dissatisfied with something.

Since both monitored shops use price comparison website Heureka.cz, we can use their customer evaluation service as one of the criteria for the evaluation of customer satisfaction. The service is asking only customers who bought at the store. It is done by sending a simple questionnaire 10 days (time limit can be changed for each store depending on the nature of goods) after making a purchase, which is previously confirmed 
by e-shop. The goal is to get an objective opinion to certify the quality of business and minimizes false evaluation.

From customer responses (see Fig. 15) can be seen that the differences in their evaluations are based on convenience of shopping. New e-shop received better reviews from customers and even comments from people included one that producer eshop should be "modernized" and need to improve its clarity.

The overall objective of ensuring the fulfillment of findability was fulfilled with increase of number of visitors from search engines. However, we wondered how well the two e-shops perform in terms of long tail phrases.

The current positions of both e-commerce sites with conversion rates for the selected period are prepared in Table II. First five phrases are general so not optimized for search engines in contrast with other five long tail phrases giving quite good conversion rate.

TABLE I EFFICIENCY OF LONG TAIL PHRASES

\begin{tabular}{|c|c|c|c|c|c|c|}
\hline \multirow{2}{*}{ Keyword } & \multirow{2}{*}{\begin{tabular}{|c|} 
New e- \\
shop \\
position \\
on \\
Seznam \\
\end{tabular}} & \multirow{2}{*}{$\begin{array}{c}\text { Producer } \\
\text { e-shop } \\
\text { position } \\
\text { on } \\
\text { Seznam }\end{array}$} & \multicolumn{2}{|c|}{$\begin{array}{c}\text { New e-shop } \\
\text { Conversion rate }\end{array}$} & \multicolumn{2}{|c|}{$\begin{array}{l}\text { Producer e-shop } \\
\text { Conversion rate }\end{array}$} \\
\hline & & & $\begin{array}{l}I V-V \\
2012\end{array}$ & $\begin{array}{l}I V-V \\
2013\end{array}$ & $\begin{array}{l}I V-V \\
2012\end{array}$ & $\begin{array}{l}I V-V \\
2013\end{array}$ \\
\hline $\begin{array}{l}\text { anatomical } \\
\text { pillow }\end{array}$ & 21 & 4 & $0,00 \%$ & $0,00 \%$ & $1,03 \%$ & $0,00 \%$ \\
\hline coach & $60+$ & 14 & $0,00 \%$ & $0,00 \%$ & $0,00 \%$ & $0,00 \%$ \\
\hline coaches & $60+$ & 37 & $0,00 \%$ & $0,00 \%$ & $0,00 \%$ & $0,00 \%$ \\
\hline $\begin{array}{l}\text { decorative } \\
\text { pillows }\end{array}$ & 8 & 3 & $0,00 \%$ & $0,00 \%$ & $0,00 \%$ & $0,00 \%$ \\
\hline $\begin{array}{l}\text { pillows and } \\
\text { covers }\end{array}$ & 30 & 21 & $0,00 \%$ & $0,00 \%$ & $5,88 \%$ & $8,33 \%$ \\
\hline $\begin{array}{l}\text { healthcare } \\
\text { pillow }\end{array}$ & 12 & $60+$ & $0,00 \%$ & $0,00 \%$ & $3,03 \%$ & $0,00 \%$ \\
\hline $\begin{array}{l}\text { mattress } \\
200 \times 180\end{array}$ & 7 & $60+$ & $0,80 \%$ & $1,66 \%$ & $1,85 \%$ & $0,00 \%$ \\
\hline Pillows 50x70 & 1 & 6 & $31,25 \%$ & $50,00 \%$ & $0,00 \%$ & $0,00 \%$ \\
\hline $\begin{array}{l}\text { covers from the } \\
\text { hollow fibers }\end{array}$ & 13 & $60+$ & $1,90 \%$ & $3,51 \%$ & $0,00 \%$ & $0,00 \%$ \\
\hline sunbed & 6 & $60+$ & $0,00 \%$ & $12,50 \%$ & $0,00 \%$ & $1,60 \%$ \\
\hline
\end{tabular}

\section{DISCUSSION}

On the Internet appear a large number of e-shops offering goods comparable to those offered by our e-shop. Therefore it is necessary to see competition between producer website and the experimental e-shop in broader context of other competitors. Both sites have to follow trends and implement new services that are available. Recently, the traffic rather stagnates than growth. The challenge for the future is to stimulate further growth in site traffic. Visitors are supposed to come through general search engine search or direct access to the site, but today's situation changed the battlefield. Important sources of traffic are also price comparison websites, discount and auction sites and high traffic source can be increasingly promoting social networking.

Most social networking sites are ideal places to share content. Simply pull up relevant material and hit the "Share" button to spread the word. If people like what they see or hear, they are likely to share it with their own network, which can increase site traffic.

According to a study [29], more than a third of respondents used daily by social media like Facebook or Twitter. For now, however, very few people $(3 \%)$ who buy through social networks. However, an opportunity for promotion at social networks as well as their potential is only a slight exaggeration virtually unlimited. Arguments for the expansion of business activities towards e-commerce to social networking sites are simple - since 2008 , the number of users on social networks increased by $500 \%$ [30].

At the beginning of the year, both companies created a profile on social networking site Facebook and the home page of both e-shops links were added to it. For now Facebook sites works most like a fan pages or blog. Both shops post news of their current and upcoming products and services and, of course, contain a link to e-shop. Based on the obtained data on the sources of traffic can be observed increasing number of visitors from this source.

Furthermore, the beauty of social networking is easy integration of Facebook and e-shop sites. Uploading content on one account, gives the option of sharing it on other networks as well.

Unlike producer e-shop, a new e-shop built in a programming environment that can automate the connection with auction sites and Facebook shop application. Therefore, in December this year, a new e-shop will be created in an environment of social network Facebook. It can open another potential new customers and additional distribution channel for the sale of goods.

\section{CONCLUSION}

Results of our experiment after reporting period show that having the same prices (no discount action) both e-commerce sites are going to have similar sales and conversion ratio. Quality of website therefore prevailed the fact that our e-shop is not manufacturer as well as the fact that we do not have offline selling channel. Nevertheless, we must conclude that price competition is much stronger than non-price. Conducted research also revealed very interesting fact. Czech online market is appropriate for discount portals. People like shopping with discount therefore using this channel bring high increase in sales.

In this article we used web analytics to study the success factors of e-commerce sites. Web analytic tools give us statistics about visits and behaviour of customers that can be used to enhance effectiveness that site.

Website quality of the new e-shop was measured according to three features; findability, usability and design. Findability was evaluated by increase of visitors coming from search engines. Prepared new e-shop proved that from March the prevalence of traffic came from search engines with the traffic as a whole tripling in the studied period.

Evaluation of design and usability is covered in conversion rate of returning visitors and partly in customer satisfaction evaluation. Returning visitors are obviously satisfied with 
website quality of e-commerce site when all other factors are obeyed.

It will be very useful to continue in observation of these two e-shops in order to find if the results will change, especially for the findability measure.

\section{ACKNOWLEDGMENT}

This paper was written with the support of the project 'Innovation and support of doctoral study program (INDOP)' No. CZ.1.07/2.2.00/28.0327 financed from EU and Czech Republic funds.

\section{REFERENCES}

[1] Centre for Retail Research, "Online Retailing: Britain and Europe 2012" [online] Available: http://www.retailresearch.org/onlineretailing.php

[2] M. Udan, "State of e-commerce in the Czech Republic in 2012", "Stav e-commerce v ČR v roce 2012" [online]. Available: https://docs.google.com/document/d/1SYzBkI4RtxKMoBbfhzH73ydApI48Ap0PZILOI3SeJE/edit?pli=1

[3] Eurostat, "E-commerce statistics" January 2013, [online]. Available: http://epp.eurostat.ec.europa.eu/statistics explained/index.php/Ecommerce_statistics

[4] Civic Consulting, "Consumer market study on the functioning of ecommerce and Internet marketing and selling techniques in the retail of goods: Final Report". September 2011, [online]. Available: http://ec.europa.eu/consumers/consumer_research/market_studies/docs/s tudy_ecommerce_goods_en.pdf

[5] C. Nistor, R. Nistor, M. C. Muntean, "E-Commerce- Winners' Choice", in vol. Selected Topics in Applied Computer Science, $10^{\text {th }}$ WSEAS International Conference on Applied Computer Science (ACS '10), Iwate Prefectural University, Japan, 4-6, ISSN 1792-4863, ISBN 978-960-474231-8, WSEAS Press, pp. 298-303, October 2010.

[6] Annual U.S, "e-commerce sales growth from 2002" [online]. Available: http://www.statista.com/statistics/172682/us-e-commerce-sales-since$2000 /$

[7] A. Bhatnagar, S. Misra and H. R. Rao, "On Risk, Convenience, and Internet Shopping Behavior", Communications of the ACM Vol. 43, No. 11, pp. 98-105, 2010.

[8] C. Dobre, A. Constantin, "The Experiences of the Online Buyers", in vol. Selected Topics in Economy \& Management Transformation, II, $5^{\text {th }}$ WSEAS International Conference on Economy and Management Transformation (EMT'10), Timisoara, Romania, ISSN 1792-5983, ISBN 978-960-474-241-7, WSEAS Press, pp. 824-830, October 2010.

[9] W.-Y. Huang, H. Schrank, and A. J. Dubinsky, "Effect of Brand Name on Consumers' Risk Perceptions of Online Shopping”, Journal of Consumer Behavior Vol. 4, No. 1, pp. 40-50, 2004.

[10] J. Park, D. Lee and J. Ahn, "Risk-Focused E-Commerce Adoption Model: a Cross-Country Study", Journal of Global Information Management Vol. 7, pp. 6-30, 2004

[11] G. Pires, J. Stanton and A. Eckford, "Influences on the Perceived Risk of Purchasing Online", Journal of Consumer Behaviour Vol. 4, No. 2: pp. 118-131, 2004.

[12] T. Teo, J. Liu, "Consumer trust in e-commerce in the United States, Singapore and China", Omega, Vol. 35 No. 1, pp.22-38, 2007.
[13] SeeWhy Research, "Is Your Website a Bucket or a Sieve?". May 2011, [online]. Available: http://seewhy.com/blog/2011/05/18/website-trafficsource-analysis/

[14] B. Yoo, N. Donthu, "Developing a scale to measure perceived quality of an internet shopping site (SITEQUAL)", Quarterly Journal of Electronic Commerce (2:1) pp 31-46, 2001.

[15] J. E. Collier, C. C. Bienstock, "Measuring service quality in e-retailing". Journal of Service Research, 8(3), pp. 260-275, 2006.

[16] H1.cz, "Use the search engines to maximum", "Vyhledávače zboží využijte na maximum". [online] Available: http://www.h1.cz/fol/2008/ zbozove-vyhledavace, 2008.

[17] Mergado, "Who is the leader of search engines", "Kdo je král vyhledávačů zboží”. In: Mergado.cz, 2012 [online] Available: http://www.mergado.cz/kral-vyhledavacu-zbozi-2

[18] Factum Invenio. "The most widely used Internet search engine is Seznam.cz", "Nejpoužívanějším internetovým vyhledávačem je Seznam.cz", 2013, [online] Available: http://www.factum.cz/ 274_nejpouzivanejsim-internetovym-vyhledavacem-je-seznamcz

[19] J. Rowley,"Product search in e-shopping: a review and research propositions", Journal of Consumer Marketing, Vol. 17 Iss: 1 pp. $20-$ $35,2000$.

[20] R. Fishkin, "Illustrating the Long Tail". November 2009, [online] Available: http://www.seomoz.org/blog/illustrating-the-long-tail

[21] eCommerceOptimalization, "eCommerce \& Shopping Cart Usability: 21 Best Practices", October 2007, [online]. Available: http://ecommerceoptimization.com/ecommerce-marketing/ecommerceshopping-cart-usability-21-best-practices/

[22] J. Maguire, "E-Commerce Best Practices: Ten Rules of the Road", January 2011, [online]. Available: http://www.ecommerceguide.com/solutions/advertising/article.php/3457431/ECommerce-BestPractices-Ten-Rules-of-the-Road.htm

[23] Spyrestudios, "Usability Best Practices For eCommerce Websites", 2012, [online] Available: http://spyrestudios.com/usability-bestpractices-for-ecommerce-websites

[24] R. Bilkova, H. Kopackova, "Using web analytics to study non-price competition in the e-commerce environment". In Advances in Computer Science: proceedings of the 6th WSEAS European Computing Conference (ECC '12). Stevens Point: WSEAS Press, 2012. s. 187-192. ISBN 978-1-61804-126-5.

[25] Z. Greenspan, "E-commerce mainstream, measurements lacking", 2012, [online] Available: http://www.clickz.com/3338561

[26] W. W. Moe, P. S. Fader, "Which visits lead to purchases? Dynamic conversion behaviour at e-commerce sites". The Wharton School, Working Paper 00-023, August 2001.

[27] V. Agrawal, L. D. Arjona, R. Lemmens, "E-performance: The path to rational exuberance". The McKinsey Quarterly, 1, pp. 30-43, 2001.

[28] KPMG, "Czech is a paradise for discount sites", "Česko je rájem slevových serverů", 2012 [online]. Available: http://www.kpmg.com/cz/cs/issuesandinsights/articlespublications/ press-releases/stranky/cesko-je-rajem-slevovych-serveru.aspx.

[29] PWC, "The average European buy online 2 to 3 times per month ", "Průměrný Evropan nakoupí na internetu 2-3krát měsíčně", 2012, [online]. Available: $\quad$ http://www.pwc.com/cz/cs/tiskovezpravy/2012/prumerny-evropan-nakoupi-na-internetu-2-3kratmesicne.jhtml.

[30] ITU News, "The rise of social networking", 2010, [online]. Available: http://www.itu.int/net/itunews/issues/2010/06/35.aspx.

\section{Creative Commons Attribution License 4.0 (Attribution 4.0 International, CC BY 4.0)}

This article is published under the terms of the Creative Commons Attribution License 4.0 https://creativecommons.org/licenses/by/4.0/deed.en_US 